\title{
Port Area of the Split Port Authority in the Function of Economic Development: Concessionaires Attitudes
}

\author{
Vice Mihanovića, Ivan Peronjab ${ }^{b}$ Luka Vukićb
}

\begin{abstract}
Measures needed to be implemented by the Port Authority at the maritime domain of the Port of Split in order to strengthen maritime traffic and stimulate economic development of the city were examined by conducting the structured questionnaire among concessionaires in the port area. The collected data were processed using the Friedman test and Sign test. Among six options, the concessionaires mostly indicated variable of building an infrastructure that will promote and attract the presence of different forms of maritime traffic in the port as the best choice for the initial purpose. Different forms of maritime traffic enable more business opportunities to compensate for the potential operating loss in case of declining maritime traffic. The Port Authority should consider the concessionaires' attitude, despite the possibility to express their own business interests within, as their business results are closely related to the size of maritime traffic in the port.
\end{abstract}

\section{KEY WORDS}

$\sim$ Maritime traffic

$\sim$ Economic development

$\sim$ Port authority

$\sim$ Port of Split

$\sim$ Concessionaires

a. Port Authority Split, Croatia

e-mail: vice.mihanovic@gmail.com

b. University of Split, Faculty of Maritime Studies, Split, Croatia

e-mail: iperonja@pfst.hr

doi: 10.7225/toms.v08.n02.006

This work is licensed under (cc) BY

\section{SPLIT-DALMATIA COUNTY IN THE FUNCTION OF THE MARITIME ECONOMY}

The Split-Dalmatia County is the fifth most developed county in the Adriatic region. Regarding the level of development, it is moderately developed county in Croatia. The economic growth of the County is of utmost importance, from the aspect of promoting the maritime economy, especially regarding the County's ability to invest in transport infrastructure (Split - Dalmatia County, 2017). Investment activities, available knowledge and skills in the form of human resources and motivating (local) economic policy are part of the factors that ensure the economic growth of a particular region (counties), where this growth is reflected in the ability of a certain region to invest in a transport infrastructure serving the economy. Developed transport infrastructure is a prerequisite for economic growth, and vice versa (New Zealand Government, 2016). The County's traffic network represents a network of traffic connections that connect the County centers with other economic centers in hinterland and foreland of the County. Considering the maritime transport, the County traffic network consists of following activities:

- regular passenger transport service lines between two or more ports inside the County and/or adjacent counties. Most of these are fast - shipping routes connecting the ports situated mostly on islands, in centers of island settlements. As the number of inhabitants on islands increases, the demand for such a type of transport is also expected to grow, especially as such transportation will become a complement to Ro-Ro passenger ferries;

- Ro-Ro passenger service lines which are natural continuation of road traffic and therefore, organized according to 
the requirements of road traffic. These services strongly depend on the economic development of a single island. It is objective to expect an increase in this type of transport, but still to a lesser extent than the expected development of regular passenger service lines;

- $\quad$ intermittent freight traffic to individual destinations, which includes the transport of small amounts of cargo by smaller vessels to remote island centers (Faculty of Maritime Studies Rijeka, 2010).

\section{CURRENT SUPPLY AND DEMAND OF MARITIME SERVICES IN THE SPLIT - DALMATIA COUNTY}

The port infrastructure in the County consists of six industrial ports, ten ports of nautical tourism (eight county and two state - owned), 65 open ports for public transport (39 local, 20 county and six international), 49 sport - recreational ports (of County significance), eight piers (five counties and three state owned), four shipyards (two county and two state-owned) and one service base.

There are a total of 15 public maritime shipping line services in the County having public procurement obligations including eight ferry lines, six fast bout catamaran lines and one classical ship line. There are also six lines without a public service obligation (CLSA, 2017).

It can be stated that the port system forms several subsystems connected to the port network, intending to connect all subjects at the national level. The development of a port within such system affects the development of the overall economy, and vice versa. That is why the development and design of the port system is a matter of national interest. The establishment of port authorities in the Republic of Croatia is one of the measures to create the economic and legal basis for the development of the national port system and the individual ports within that system, regardless of whether the port has state or county significance (Jugović et al., 2009).

\section{PORT AUTHORITY OF SPLIT-DALMATIA COUNTY AND THE SPLIT PORT AUTHORITY}

The significance of maritime transport for the economic development of counties in the Republic of Croatia in general, and particularly in the Split - Dalmatia County, is visible in concrete terms within the applicable legal regulations. Namely, by the Maritime Law and Seaports Act (Croatian Parliament, 2009), counties are entitled to establish county port authorities with the aim to contribute to maritime development, and main overall objective of improved management of maritime affairs in their area.

Ports open to public traffic are classified according to the size and importance as of: economic interest for the Republic of Croatia,

county's significance,

local importance.

The founder of the port authority for the ports of special international economic interest of the Republic of Croatia is the Government of the Republic of Croatia, and the county's assembly for the county level ports. Six port authorities open to public transport have been established in Croatia having particular (international) economic interest. These are the ports of Rijeka and Ploče, principally intended for freight traffic, and the ports of Zadar, Split, Šibenik and Dubrovnik having primarily activity of passenger traffic. Based on the decision to establish the port authority, a port area is defined, i.e. the maritime domain over which the port authority's competence spreads. Port activities along with infrastructure and superstructure facilities are also established, and relevant by-laws are adopted, thus creating a legal framework for the development of the national port system and certain ports within it (Batur, 2010).

Accordingly, on March 1st, 1999, the Port Authority of the Split - Dalmatia County was founded based on the Maritime Domain and Seaports Act and the Split - Dalmatia County Statute. The purpose of its founding is to manage, build and utilize ports open for public traffic of county and local importance.

The Split - Dalmatia County Port Authority's activities are as follows:

- concern for the construction, maintenance, management, protection and improvement of the maritime domain that represents the port area,

- construction and maintenance of the port infrastructure, financed from the budget of the founder of the port authority,

- expert supervision over the construction, maintenance, management and protection of the port area (port infrastructure and superstructure),

- ensuring permanent and uninterrupted performance of port traffic, technical-technological unity and navigation safety,

- $\quad$ ensuring the provision of services of general interest or for which there is no economic interest of other economic entities,

- harmonization and supervision of the operation of concessionaires performing economic activities in the port area,

- making decisions to establish and operate a free zone in the port area and regulate free zone and other activities by the Law (Port Authority of Split - Dalmatia County, 2017).

By the founding of the Split Port Authority, in sense of investment in port infrastructure and superstructure, the most prosperous period of the Split - Dalmatia County has taken place. This trend has resulted in significant maritime development. It is determined by improved connection of the coastal area with the islands of the Split - Dalmatia County, as new ports are being built and existing ones are being expanded, thus creating preconditions to accommodate more advanced and larger vessels. Furthermore, the development of maritime activities 
in the area of Split - Dalmatia County is particularly evident in the development of nautical tourism activities, which have had remarkable economic indicators in recent years. To conclude, the development of maritime traffic in the area of Split - Dalmatia County is extremely important, especially if viewed in the context of improvement of quality of life on islands (Split Port Authority, 2017).

\section{MATERIAL AND METHOD}

Confirming the above mentioned data, that maritime traffic in a particular port area under the management of a particular port authority undoubtedly contributes to economic development, the aim of this research is to investigate what needs to be done at the maritime domain under the management of the Split Port Authority in order to stimulate greater economic development of the city. The research is based on the perception of economic entities (concessionaires) at the maritime domain of the Split Port Authority concerning the state and perspectives of maritime transport in the Port of Split.

A structured questionnaire was used in the research, conducted for this paper, as a data collection method. With the use of questionnaire, the attitudes of concessionaires carrying out economic activities were collected in the port area of Split. The survey was conducted in the city of Split in October 2017 using the online Google Docs program. All concessionaires operating in the port area of Split were requested to participate in the research. It is important to emphasize that economic activity in the port area can only take place through a concession. There were 80 concessionaires engaged in maritime and allied activities in the port area of the city of Split at the time of conducting the research. The questionnaire was sent to all 80 addresses. The questionnaire was filled in by 23 respondents, i.e., $28 \%$ respectively. Although the response rate was low, it is important to note that among the respondents who responded entirely to this questionnaire were concessionaires who carried out $80 \%$ of the economic activities in the Port of Split and therefore, the survey results can be considered representative.

Through the questions, six (6) variables (v1 - v6) were offered to the concessionaires to assess at what extent each of them, in their opinion, could contribute to the better economic development of the city of Split. The variables are shown in Table 1.

Table 1.

Variables of the conducted research.

Invest in optimizing a superstructure that has so far not been appealing to economic entities v1

Build an infrastructure that would better connect the port with its gravitational area v2

$\begin{array}{ll}\text { Establish an integrated port IT system } & \text { v3 }\end{array}$

Build infrastructure that will encourage and attract the presence of different forms of maritime traffic

Enter a maritime domain, that is not included, in the land register

Define port tariffs (dues and fees) according to the competition in the surrounding area

v4

The questions offered the answers with Likert's one - tofive- scale estimating (Šundalić and Pavić, 2013) as follows:

- 1 - irrelevant;

- 2 - not relevant;

- 3 -neither important nor irrelevant;

- 4 -important

- 5 - completely important.

The data collected in survey were analyzed with the use of statistical programs IBM SPSS Statistics and MS Excel. The significance of data was controlled by descriptive statistics (Burić, 2018) and nonparametric statistical assays as Friedman's chisquared test (Charles Zaiontz, 2017) and Sign Test (Shier, 2004).

\section{RESULTS}

The results of the research are shown in Table 2 based on the scoring principle of Likert scale (1, 2, 3, 4, and 5). The most acceptable answer on the questionnaires scale of importance, of what should be done on the maritime domain of the Port of Split in order to stimulate greater economic development, refers to the variable v4 (Build infrastructure that will encourage and attract the presence of different forms of maritime traffic), which was accepted by $87 \%$ of the respondents, and $52.2 \%$ of respondents consider this variable to be of utmost importance. 
Table 2.

Activities to be undertaken on the maritime domain of the Port of Split to boost greater economic development.

\section{What should be done on the maritime domain of the port area of the Port of Split to encourage greater economic development?}

\section{Irrelevant \\ Not
relevant}

(2) (1)

Neither
important
nor
irrelevant

(3)
Important

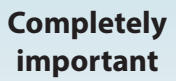

(5)

(4)

Invest in optimizing a superstructure that

2

5

No answer has so far not been appealing to economic entities ( $\mathrm{v} 1$ )

$(8.7 \%)$

$(21.7 \%)$

6

8 1

Build an infrastructure that would better 0

4

1

$(26.1 \%)$

$(34.8 \%)$

connect the port with its gravitational area (v2)

$(0.0 \%)$

(17.4\%)

$(4.3 \%)$

9

8

1

Establish an integrated port IT system (v3)

3

3

2

$(39.1 \%)$

$(34.8 \%)$

\begin{tabular}{lcccccc} 
& $(13.0 \%)$ & $(13.0 \%)$ & $(8.7 \%)$ & $(17.4 \%)$ & $(39.1 \%)$ & $(8.7 \%)$ \\
\hline $\begin{array}{l}\text { Build infrastructure that will encourage and } \\
\text { attract the presence of different forms of } \\
\text { maritime traffic (v4) }\end{array}$ & 0 & 1 & 1 & 8 & 12 & 1 \\
\hline $\begin{array}{l}\text { Enter a maritime domain, that is not } \\
\text { included, in the land register (v5) }\end{array}$ & $(0.0 \%)$ & $(4.3 \%)$ & $(4.3 \%)$ & $(34.8 \%)$ & $(52.2 \%)$ & $(4.3 \%)$ \\
\hline $\begin{array}{l}\text { Define port tariffs (dues and fees) according } \\
\text { to competition in the surrounding area (v6) }\end{array}$ & $(13.0 \%)$ & $(8.7 \%)$ & $(34.8 \%)$ & $(13.0 \%)$ & $(26.1 \%)$ & $(4.3 \%)$ \\
\hline
\end{tabular}

Considering that these variables are ordinal (sequential) ones, Friedman's test for dependent variables was used to determine whether the differences between these six statements are statistically significant. The results are shown in Table 3 and Table 4.

\section{Table 3.}

Comparison of the average rank of importance of a claim of what needs to be done on the maritime domain of the Split Port Authority to encourage greater economic development.

\section{Options}

Invest in optimizing a superstructure that has so far not been appealing to economic entities

Build an infrastructure that would better connect the port with its gravitational area

Establish an integrated port IT system

Build infrastructure that will encourage and attract the presence of different forms of maritime traffic

Enter a maritime domain, that is not included, in the land register

Define port tariffs (dues and fees) according to the competition in the surrounding area
Average rank

3.21

3.67

3.29

4.12

2.67

4.05 
in the port and surrounding area. The advantages of the presence of the various aspects of maritime traffic and, consequently, the related economic activities, are especially important in times of major disturbances in the market on which, given the international character of maritime traffic and the global impacts arising there from, it can't be significantly influenced. If a certain port business activity of maritime traffic recorded a traffic decline (in 2017, the Port of Split recorded a decrease in passenger and vehicle traffic on international voyages, but also an increase in the number of passengers and vehicles in domestic traffic with total growth by $6 \%$ ) (CBS, 2017), there is a possibility to compensate the decrease of certain traffic activity by increase of other form of traffic that exists in the port. It is necessary to develop the port infrastructure and superstructure that increases the port capacity and thus creates preconditions for attracting various aspects of maritime traffic. Furthermore, it is extremely important to study the traffic trends in the surrounding ports (which are, as a rule, also the main competitors), to identify the possibility to attract additional modes of maritime traffic. In addition to investment in port infrastructure and superstructure, additional traffic can be attracted by stimulating tariff policy of entities involved in shipping and shipping costs. Businesses operating in the port area have direct benefit of increasing the existing traffic or attracting a new form of maritime traffic (including cargo traffic activities) in order to negotiate a reduction of their service prices and ability to work together towards acquiring potential new users of their services. All these suggested measures affect and increases the level of port competitiveness.

According to the legal regulations of the Republic of Croatia, the Port Authority has been established to manage maritime domain (ports), meaning that it should invest, build and maintain the port infrastructure and superstructure. Port Authority, as a non-profit state institution, accumulates income from port dues and fees as well as concession fees and reinvests the retrieved revenue in the development of the port area. It is therefore of the utmost importance that the management of the port administration has a clear vision in which direction the port should be developed through investments in the port infrastructure and superstructure. Furthermore, authorized concessionaires may also invest in the port area if they have valid permission for these activities. Port authorities should work to improve attractiveness of the port area for investments of potential concessionaires.

\section{CONCLUSION}

The main implication and recommendation of concessionaires performing business activities in the related port area is to build infrastructure at maritime domain under the management of the Split Port Authority that will encourage and attract the presence of different forms of maritime traffic and in that way, increase maritime transport and strengthen the economic development of the city. The provision of suggested measures would probably improve the concessionaires' business results too. Continuous and systematic investment in port infrastructure and superstructure is needed. In this way the port system can better deal with the changing demand of maritime transport and as an overall result, generate positive economic effects and development.

\section{REFERENCES}

Batur, T., 2010. Legal status of the seaports and port policy in Republic of Croatia. Zbornik radova Pravnog fakulteta u Splitu, 47(3), pp. 677-692.

Burić, I., 2018. Uvod u deskriptivnu i inferencijalnu statistiku, Odjel za psihologiju Sveučilište u Zadru, Zadar, Hrvatska.

CBS (Croatian Bureau of Statistics), 2017. Passenger traffic in selected seaports in the third quarter of 2017. Available at: www.dsz.hr, accessed on: 22 November 2017.

Charles Zaiontz, 2017. Real Statistics Using Excel, Friedman test. Available at: http:// www.real-statistics.com/anova-repeated-measures/friedman-test/, accessed on: 25 November 2017

CLSA (Costal Liner Service Agency), 2017. Available at: http://www.agencija-zolpp. hr/, accessed on: 2 November 2017.

Croatian Parliament, 2009. The Maritime Domain and Seaports Act: the consolidated text of the law. NN 158/03, 100/04, 141/06, 38/09.

Faculty of Maritime Studies Rijeka, 2010. Study of the maritime and port system of the wider area of the city of Split, University of Rijeka, Rijeka, Hrvatska.

Jugović, A., Seršić, V. and Debelić, B., 2009. Economic interest association of port authorities. Pomorstvo, 23(2), pp.459-476.

New Zealand Government, 2016. Contribution of Transport to Economic Development, Ministry of Transport. Available at: http://www.transport.govt. nz/assets/Uploads/Our-Work/Documents/edt-Contribution-of- transport-toeconomic-development.pdf, accessed on: 2 November 2017.

Port authority County of Split-Dalmatia, 2017. Available at: http://www.luckauprava-sdz.hr/, accessed on: 3 November 2017

Shier, R., 2004. Mathematics Learning Support Centre, Statistics: The sign test. Available at: https://www.lboro.ac.uk/media/wwwlboroacuk/content/mlsc/ downloads/2.1_signtest.pdf, accessed on: 25 November 2017.

Split - Dalmatia County, 2017. Information. Available at: https://www.dalmacija.hr/ zupanija/informacije, accessed on: 28 November 2017.

Split port authority, 2017. Split, Croatia. Available at: http://portsplit.com/, accessed on: 2 November 2017.

Šundalić, A. and Pavić, Ž., 2013. Uvod u metodologiju društvenih znanosti, Ekonomski fakultet u Osijeku, Sveučilište J.J.Strossmayera, Osijek, Hrvatska. 